\title{
Change in Physico-chemical Characteristic of River Kshipra during the Simhasth Festival
}

\author{
Shrikant Gangwar ${ }^{1 *}$, Shivdayal Meena ${ }^{1}$, Kalpana Dave ${ }^{2}$ and Ashwani Wanganeo ${ }^{1}$ \\ Department of Environmental Science and Limnology, Barkatullah University, Bhopal, India \\ *Corresponding author
}

A B S T R A C T

\begin{tabular}{l} 
Ke y w o r d s \\
Kshipra River, \\
simhasth, \\
physico-chemical \\
parameters. \\
\hline Article Info \\
\hline $\begin{array}{l}\text { Accepted: } \\
12 \text { April } 2017 \\
\text { Available Online: } \\
10 \text { May } 2017\end{array}$ \\
\hline
\end{tabular}

\section{Introduction}

In order to achive salvation an opertunity coming after every 12 years in the Hindu mythlogy is celebrated with lot of pomp and show along some sacred river courses. A mammoth public gathers round some of the rivers to take a bath, in oder to unburden themselves of the wordly sins. Whily doing so they knowingly or unknowingly overburden the rivers (especially thosen with low flow) beyond their carrying capacity thus raisng an alarm for their conservation and management.

River kshipra the present place of work was visited by millions of people every day during the month long festival celebrate after the gape of 12 years from 15 April to $21^{\text {st }}$ May, 2016. On the last day of the festival around 1.5 crore public took a holy dip in the said river, which experienced fish kill near Ram ghat and Gow ghat after gape of one month, even after mixing the Narbada river water into it for maintaining a sizeable level of the river during the month long festival. The river attains maximum flow during monsoon season only, and latter on takes shape of cesspools due to non-flow period.

\section{Study area}

The study area "Kshipra River" is one of the rivers sanctified in Hinduism. The holy city of Ujjain is situated on its east bank and the famous Ramghat is situated close to Mahakal temple. That is why Ramghat is considered the best place for bathing during Simhastha fair. 
The river originates at KakriBardi hill of Vindhya Range, $20 \mathrm{~km}$ south-East of Indore city near a small village Ujjain $\left(22^{\circ} 31^{\prime}\right.$ North and $76^{\circ}$ East). It flows towards north across the Malwa Plateau through Dewas, Indore and Gwalior districts of the state and joins Chambal river near Kalu-Kher village $\left(23^{\circ}\right.$ $53^{\prime} \mathrm{N}$ and $\left.75^{\circ} 31^{\prime \prime} \mathrm{E}\right)$. The overall course of the Shipra river is $190 \mathrm{Km}$ with a catchment area of $5600 \mathrm{~km}^{2}$. Main tributaries of Shipra are Khan River near Ujjain and Gambhir River near Mahidpur (Kumar et al., 2015)

Samples where collected near Ramghat before, during and after the culmination of the Simhasth festival in order to ascertain the anthropogenic impact on the river ecosystem (Fig. 1).

\section{Materials and Methods}

The physico- chemical analysis of the water samples was conducted following the standard procedures as given in APHA.

\section{Result and Discussion}

The data revealed that there were considerable variation in some of the examined samples. The changes in various physico-chemical parameters of Kshipra river at "Ram ghat" (Sampling site) are summedup in table 1 and figure 1.

\section{PH}

The measurement of $\mathrm{pH}$ of water is important because chemical and biochemical reaction in an aquatic body takes place at a particular $\mathrm{pH}$ which plays an important role in productivity of River. During investigation maximum $\mathrm{pH}$ (7.7 units) was observed before the festival while after the one month long festival a small reduction by 0.2 units was observed in the $\mathrm{pH}$ value.

\section{Conductivity}

Conductivity provides a very rapid means of obtaining good approximate knowledge of total dissolved solids concentration and salinity of water sample. During the study period minimum value $\left(190 \mu \mathrm{Scm}^{-1}\right)$ was recorded before the start of the festival while maximum value $\left(500 \mu \mathrm{Scm}^{-1}\right)$ was obtained after the culmination of the festival (Table 1).

\section{Chloride}

The most important source of chloride in water is from the discharge of domestic sewage. During the present study the maximum value obtained for chloride was $49.99 \mathrm{mg} / 1$ and the minimum value was 39.99 $\mathrm{mg} / 1$. According to WHO (1964) guidelines the safe value of chloride is $250 \mathrm{mg} / \mathrm{l}$ (Table $1)$.

\section{Hardness}

Hardness is primarily a measure of the amount of calcium and magnesium salts. Calcium and magnesium occurs mainly in combination with bicarbonate, Sulphate and chlorides. During the present study the results indicate that samples taken before $(60 \mathrm{mg} / \mathrm{l})$ the simhastha festival; during the festival (60 $\mathrm{mg} / \mathrm{l})$ and after the festival $(64 \mathrm{mg} / \mathrm{l})$ recorded negligible variation (Table 1 ).

\section{Total Alkalinity}

Alkalinity is a measure of the presence of bicarbonates, carbonates and hydroxide constituents. The alkalinity values found before $(54 \mathrm{mg} / \mathrm{l})$ and during the festival (56 $\mathrm{mg} / \mathrm{l})$ recorded no significant variation however, and after the culmination of the festival the values rose to $210 \mathrm{mg} / \mathrm{l}$ (Table 1). 
Fig.1 Sampling site (Ram ghat) on Kshipra river

\section{Madhya Pradesh}
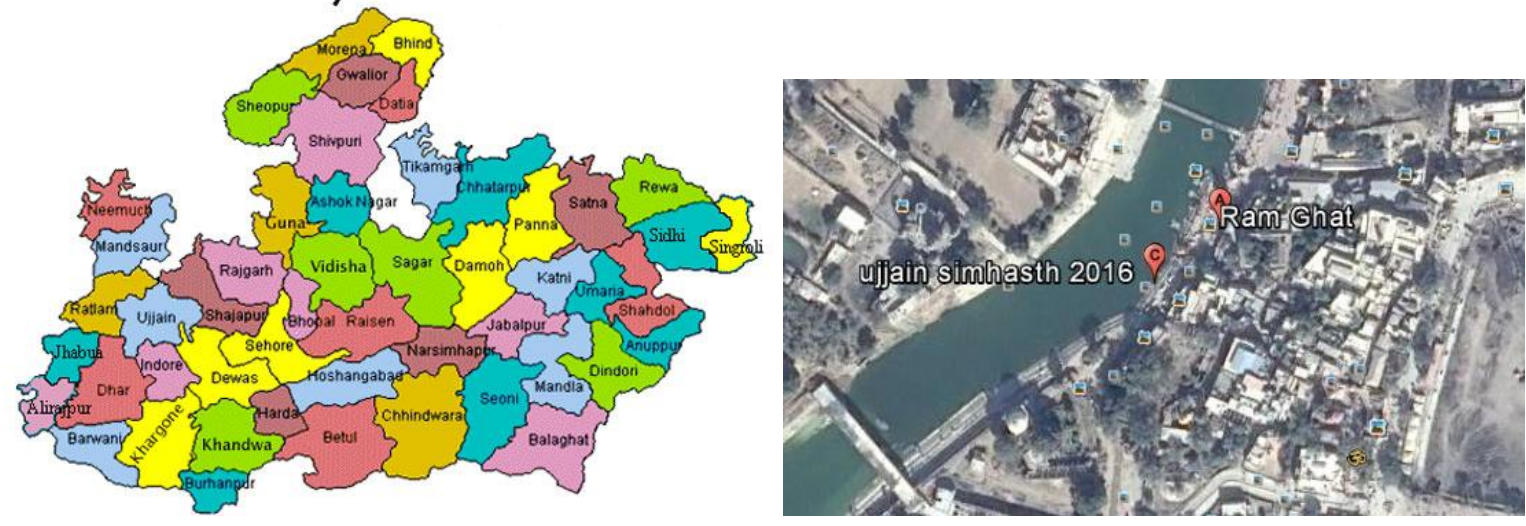

Table.1 Change in water quality parameters on account of mass bathing during the Festival period.

\begin{tabular}{|l|c|c|c|c|}
\hline Parameters & & \multicolumn{3}{|c|}{ Sampling dates } \\
\hline & Units & $9 / 4 / 2016$ & $15 / 5 / 2016$ & $21 / 5 / 2016$ \\
\hline $\mathrm{pH}$ & & 7.7 & 7.5 & 7.5 \\
\hline Conductivity & $(\mu \mathrm{S} / \mathrm{cm})$ & 190 & 400 & 500 \\
\hline $\mathrm{DO}$ & $(\mathrm{mg} / \mathrm{l})$ & 5.8 & 2.0 & - \\
\hline Total Alkalinity & $(\mathrm{mg} / \mathrm{l})$ & 54 & 56 & 210 \\
\hline Chloride & $(\mathrm{mg} / \mathrm{l})$ & 49.99 & 39.99 & 41.99 \\
\hline Total hardness & $(\mathrm{mg} / \mathrm{l})$ & 60 & 60 & 64 \\
\hline Nitrite & $(\mu \mathrm{g} / \mathrm{l})$ & $\mathrm{ND}$ & 2.7 & 1.32 \\
\hline Orthophosphate & $(\mu \mathrm{g} / \mathrm{l})$ & $\mathrm{ND}$ & 2.28 & 5.6 \\
\hline Nitrate & $(\mu \mathrm{g} / \mathrm{l})$ & 29 & 243 & 681.36 \\
\hline
\end{tabular}

Where: $\mathrm{ND}=$ Not detected

Table. 2 Variation in various parameters after the addition of water from river Narmada

\begin{tabular}{|l|l|l|l|}
\hline & & 2011 (Savita,2013) & $\begin{array}{l}2016 \text { (present } \\
\text { work) }\end{array}$ \\
\hline Parameters & Units & $\begin{array}{l}\text { Minimum- } \\
\text { Maximum }\end{array}$ & $\begin{array}{l}\text { Minimum - } \\
\text { Maximum }\end{array}$ \\
\hline pH & & $8.37-8.42$ & $7.5-7.7$ \\
\hline TDS & $(\mathrm{ppm})$ & $746.21-762.52$ & $150-248$ \\
\hline Total Alkalinity & $(\mathrm{mg} / \mathrm{l})$ & - & $54-210$ \\
\hline Chloride & $(\mathrm{mg} / \mathrm{l})$ & $156.6-179.32$ & $39.99-49-99$ \\
\hline Total Hardness & $(\mathrm{mg} / \mathrm{l})$ & $324.16-352.12$ & $60-64$ \\
\hline Nitrate & $(\mu \mathrm{g} / \mathrm{l})$ & $61,200-62,800$ & $29-681.36$ \\
\hline
\end{tabular}


Fig.1 Variation in various parameters in ambient water of River Kshipra during the festival period

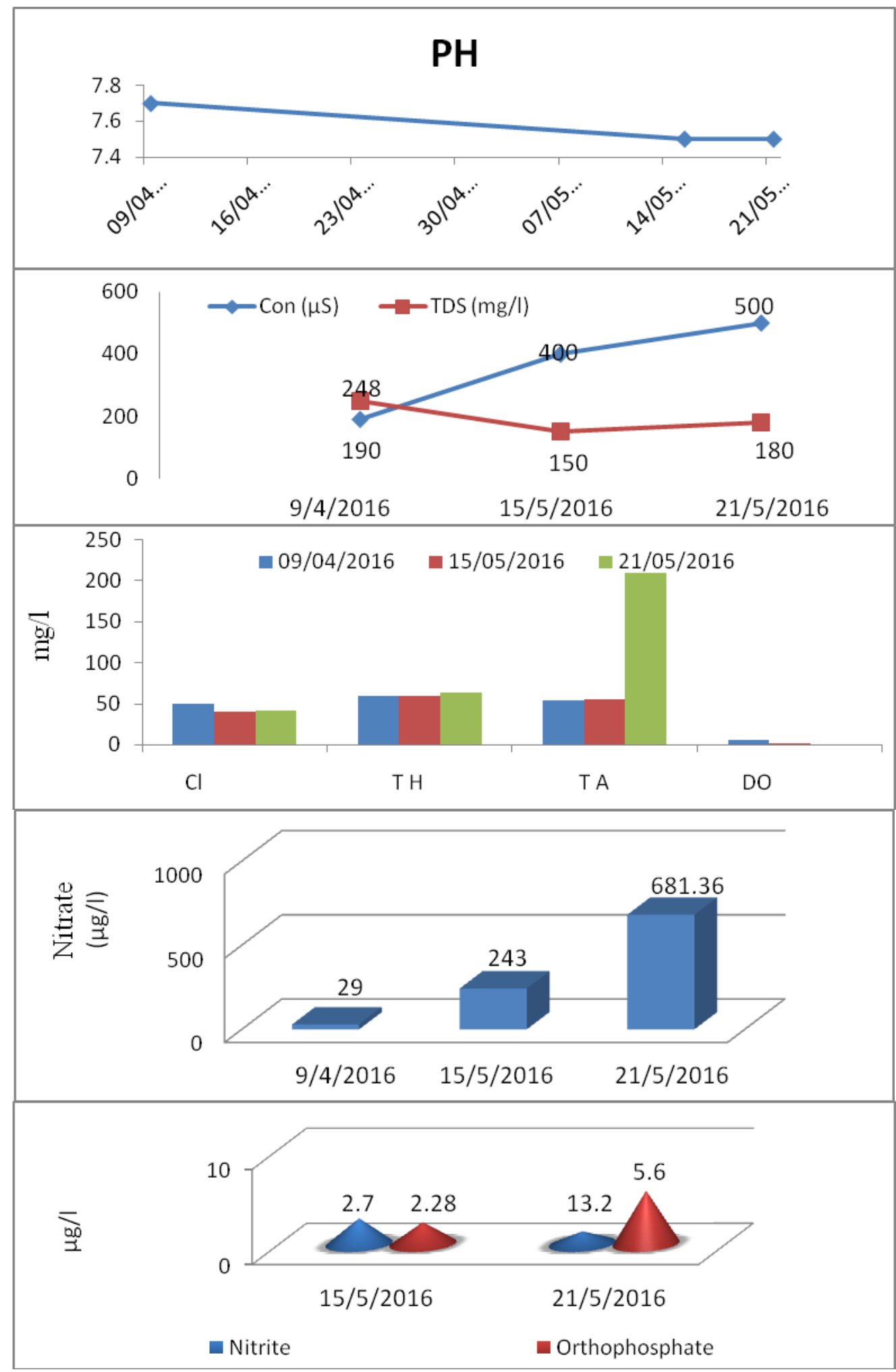




\section{Dissolved oxygen}

DO is a very important parameter of water quality and an index of physical and biological processes going on in the water. It may be present in water due to direct diffusion from air and photosynthetic activity of autotrophs. During the present festival minimum DO value of $2.0 \mathrm{mg} / \mathrm{l}$ and maximum value of $5.8 \mathrm{mg} / \mathrm{l}$ was observed (Table 1).

\section{Nitrite}

Nitrite is the partially oxidized form of nitrogen, and it occurs in lower concentration than nitrate in natural waters. The surface water concentration of nitrite-nitrogen in the Kshipra River ranged between $2.7 \mu \mathrm{g} / \mathrm{l}$ (before simhastha festival) to $1.32 \mu \mathrm{g} / \mathrm{l}$ after the culmination of the festival (Table 1).

\section{Nitrate}

Nitrate indicates the pollution in water due to mixing of sewage in the surface waters. The samples analyzed during the simasth festival varied from a minimum value of $2.9 \mu \mathrm{g} / \mathrm{l}$ to a maximum value of $681.36 \mu \mathrm{g} / \mathrm{l}$.

\section{Phosphate}

The study carried out the 2016 simhastha festival showed that the concentration of phosphate ranged between a minimum of 2.28 $\mu \mathrm{g} / \mathrm{l}$ to a maximum of $5.6 \mu \mathrm{g} / \mathrm{l}$.

\section{Calcium}

The value of calcium was found to range from $60 \mathrm{mg} / \mathrm{l}$ to $112 \mathrm{mg} / \mathrm{l}$ which is slightly higher than the permissible limit as prescribed by WHO but is well within the permissible limits as prescribed by BIS standards. The main sources of calcium in natural water are various types of rocks, industrial waste and sewage.

\section{Sodium and potassium}

During the present study in Ksipra River sodium recorded a value of $44.84 \mathrm{mg} / \mathrm{l}$ while potassium recorded a value of $6.25 \mathrm{mg} / 1$. WHO prescribed in limit of $200 \mathrm{mg} / \mathrm{l}$ for sodium in portable water.

Kumar and Galkate (2015) reported very little flow in the month of November and December and no flow during January to June in River Kshipra. However, the link between Narmada and Kshipra River besides enhancing the water quality has also transformed the ephemeral quality of Kshipra River to perennial form.

Before the addition of water from the Narmada River almost all parameters recorded very high values in comparison to the present study (Table 2).

The water analysis conducted before, during and after the Simhastha festival revealed maximum enhancement in Conductivity, Total Alkalinity, and Nitrate nitrogen values. Total Hardness and ortho- phosphate also revealed little augmentation in their values (Table 2).

On the other hands no significant variation was recorded in PH, TDS, and Chloride however, DO recorded reduction in its values during the festival period (Table 1) emphasizing the anthropogenic impact on the system.

\section{References}

Adoni, A.D., Joshi, G., Ghosh, K., Chourasia, S.K., Vishya, A.K., Yadav, M. and Verma, H.G. 1985. workbook on limnology, Pratibha Publishers, Sager, pp 1-216.

APHA. 2012. Standard method for examination of water and waste and water APHA, WPCF, $18^{\text {th }}$ edition, new 
York.

Kumar, K.S., Tiwari, H.L., and Galkate, R.V. 2015. Water Availability Assessment in Shipra River, IJRET, 4(11): 126-130.
Savita Dubey. 2013. Analysis of PhysicoChemical Parameters of Kshipra River Water of Ujjain, India. Int. Res. J. Environ. Sci., (7): 1-4.

\section{How to cite this article:}

Shrikant Gangwar, Shivdayal Meena, Kalpana Dave and Ashwani Wanganeo. 2017. Change in Physico-chimical characteristic of River Kshipra during the Simhasth festival. Int.J.Curr.Microbiol.App.Sci. 6(5): 1331-1336. doi: https://doi.org/10.20546/ijcmas.2017.605.144 